\title{
The Origins and Products of Japanese Lesson Study
}

\begin{abstract}
The aim of this paper is to provide an overview of the Lesson Study and its main product - Problem Solving Approach, based on the relevant literature research and direct observations by the author of the paper. Japanese Lesson Study is recognized as successful methodology in Mathematics education. In the Western European countries and the United States, Lesson Study is usually perceived as a professional development process that engages Japanese teachers to systematically examine their practice with the goal of becoming more effective. However, Lesson Study is more than professional development. It is a scientific activity for teachers based on methodology introduced in 1880s (Isoda, 2011). The products of Lesson Study are not limited only to what participants had learned from particular class and post-class reflective discussion. It also includes the development of local theories in Mathematics education. One of theories of teaching Mathematics that emerged from Lesson Study is Problem Solving Approach, which is commonly known as Japanese teaching approach and theory of teaching about learning how to learn (Stigler \& Hiebert, 1999). The aimed product of this approach is the ability of students to learn mathematics independently.
\end{abstract}

Keywords: lesson study, problem-solving approach, Mathematical education.

\section{Introduction}

International assessments in Mathematics reveal consistent high performance of students from Japan and other Asia Pacific countries. This puts educational systems and practices of Asia Pacific countries into focus of interest for the Mathematics education community as well as curriculum policy, design and development community. One of the topics of worldwide attention is the Japanese Lesson Study, which is recognised as an engine for above-average achievement of Japanese students. Lesson Study is

1 kpjanic@gmail.com a process where teachers collaboratively develop ways to foster students' what may some call 'flexible' understanding of Mathematics. Lesson Study has been used in Japan since 1880's with the purpose of improving the preparation of a lesson, sequence of lessons or a selected topic, to predict pupils' reaction, and to review and improve a lesson studied in the cycle of improvement. Generally, the lessons are based on a problem-solving approach in which teachers educate pupils to think for themselves. In USA and some European countries Lesson Study is usually perceived as a professional development process that engages teachers to systematical- 
ly examine their practice with the goal of becoming more effective. However, Lesson Study is more than the professional development. The aim of this paper is to provide an overview of the Lesson Study and its main product - Problem Solving Approach, based on relevant literature research and direct observations by the author of the paper.

\section{Meaning and origin of Lesson Study}

Lesson Study is a process in which teachers progressively and systematically strive to improve their teaching methods by working with other teachers to examine and critique each others' teaching techniques. This examination centers on teachers working collaboratively on a number of "study lessons". Working on study lessons involves planning, teaching, observing, reflecting and critiquing the lessons. To provide focus and direction to this work, the teachers select an overarching goal and related research question that they want to explore. The research question then serves to guide their work on all aspects of the lessons they study. The origins of Lesson Study can be traced to educational practice in the Meiji period of Japan. It began from the observation of teaching methods in whole classroom teaching which had been firstly introduced in schools beyond the temple school culture which used tutorial teaching methods. According to Wakabayashi and Shirai (cited in Isoda, 2011), Lesson Study first began at the Tokyo Normal School, which later became the University of Tsukuba, in 1870s. From the very begining teachers were focused on argumentation through questioning instead on lecture style method. People observed the ways of teaching for knowing how-to conduct teaching and learning process (Makinae, 2010). As a result, Teachers' Canon was published by the Normal School in 1873, which described the etiquette for entering classroom, for observation of lessons, and for avoiding the negative effects of observations (Inprasihta, 2006). Since then Lesson Study has functioned in Japan as a way of enabling teachers to develop and study their own teaching practices and shed light on the local theories of education.

Derived from the Japanese words jugyo kenkyuu, the term lesson study was coined in 1999 by Makoto Yoshida in his doctoral dissertation Lesson study: A case study of a Japanese approach to improving instruction through school-based teacher development (Takahashi \& Yoshida, 2004). It can also be translated and interpreted as research lesson.

Generally, the following four dimensions of Lesson Study can be pointed out:

- The collaborative activity,

- The form of research related to lesson,

- Importance that the pupils are kept at the heart of the process,

- The understanding of the process that is primarly focused on content and pupils rather then on technology and tools.

The cycle of the lesson study goes as follows. While working on a study lesson, teachers jointly draw up a detailed plan for the lesson, which one of the teachers uses to teach the lesson in an actual classroom and other members of the group observe. This group of observes may be joined by others: observers could be just the faculty within a school, or a wider group: teachers from several schools sometimes joined the university instructors and supervisors from the board of education. Usually observers record lessons, as well as their impressions of lessons in multiple ways. A discussion of the lesson follows. Typically, such a gathering begins with presentations by the teachers who taught and co-planned the lesson, followed by free or structured discussion. Upon review of the lesson, another teacher usually implements it in a second classroom, while group members again observe. The group will come together again to discuss the observed instruction. Finally, the teachers produce a report of what their study lessons have taught them, particularly with respect to their research question. 
Research lessons are designed to bring to life in a lesson a particular goal or vision of education. The whole faculty chooses a research theme or focus. Typically, it is a broad goal or vision of education that goes beyond a specific subject matter and lesson. Table 1 shows samples of Lesson Study Topics with broad goals which were implemented in Japan on national level. (Isoda, 2011).

\section{Table 1. Lesson Study Topics}

\begin{tabular}{|cl}
\hline Period & \multicolumn{1}{c}{ Lesson Study topic } \\
\hline 1880 s & $\begin{array}{l}\text { Pestalozzi Method and Dialog Method (in- } \\
\text { cluding argumentation/ discussion/dialogue } \\
\text { between teacher and students) }\end{array}$ \\
\hline 1910 s & $\begin{array}{l}\text { Mathematics for Life (including problem } \\
\text { posing) }\end{array}$ \\
\hline $1930 s$ & $\begin{array}{l}\text { Curriculum Integration in Mathematics (in- } \\
\text { cluding Open-Ended Problems) }\end{array}$ \\
\hline $1950 s$ & $\begin{array}{l}\text { Core curriculum movement based on social } \\
\text { studies }\end{array}$ \\
\hline $1960 s$ & $\begin{array}{l}\text { Mathematical Thinking (Japanese way of } \\
\text { New Math) }\end{array}$ \\
\hline $1970 s$ & $\begin{array}{l}\text { Open-Ended Approach and Problem Solving } \\
\text { Approach }\end{array}$ \\
\hline $1980 s$ & Problem Solving \\
\hline
\end{tabular}

The table allows us to follow the chronology of changes in the Lesson Study topics and approaches for developing children in Japan during one century.

\section{Japanese Lesson Study features}

Japanese Lesson Study is recognized as having the following elements (Isoda, 2011): determined process/cycle, open classroom ${ }^{2}$, theme or focus for Lesson Study, lesson plan, teachers acting as researches, results, sequential experience for sharing the heritage and development of children who learn by/for themselves. We will take a closer look into these features.

1. In short, the process of Lesson Study can be described as process: plan, do and see. The activities related to 'plan, do, and see' are conducted collaboratively by teachers and repeated in cycles. The first stage of the Lesson Study process is preparation or goal-setting and planning (kyozai kenkyu). This process begins with finding and selecting materials relevant to the purpose of the lesson. It is followed by joined work of teachers in refining the lesson design based on the actual needs of the pupils and tying all of this information together into a lesson plan. Based on the joint teaching plan, teacher conduct a lesson in an open classroom while the group members and outsiders observe the class, taking detailed notes regarding the reactions and engagement of the students. This represents second stage of cycle - teaching the research lesson enables the lesson observation (koukai/kenkyu jugyo). Review session (jugyo kentoukai) is held for all observers after the research lesson. The group comes together to discuss and reflect on the instruction witnessed and what it taught them about the goal they set out to explore.

The reflective nature of Lesson Study has as its premise the collaboration between participants, and throughout the process emphasis is placed on how pupils view and comprehend the subject matter being taught (Sarkar at al., 2010). The methodology inherent in conducting Lesson Study leads to the need for effective documentation of classroom observations. One of such documents is presented in Table 2. It is primarily designed for self-evaluation, however it could be used by all participants in a lesson study group. 


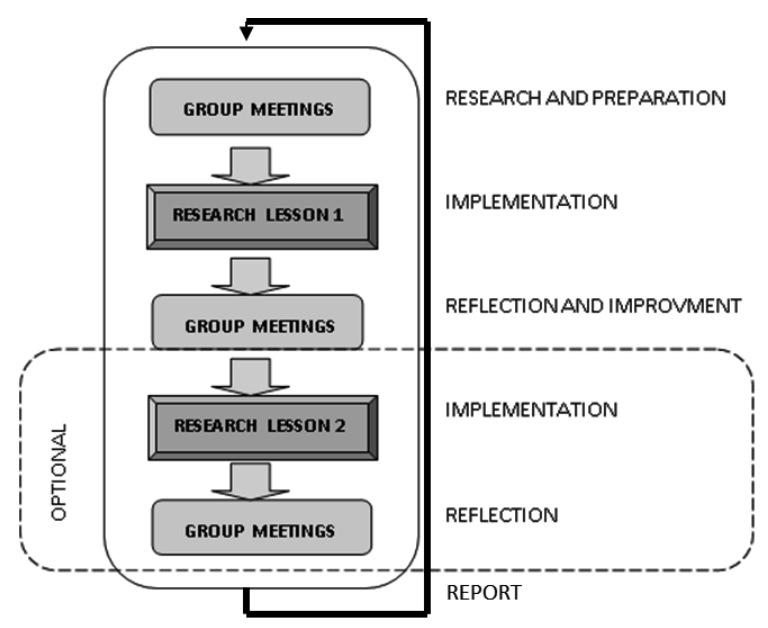

Figure 1. Typical Lesson Study cycle

\section{Table 2. Lesson Planning Checklist: Self-Evaluation (addapted from Isoda and Olfos, 2009)}

Problem Posing
$\begin{aligned} & \text { 1. The lesson sets tasks that can be solved in a variety of different ways by applying previously learned knowledge, } \\ & \text { and presents the content to be learned. }\end{aligned}$
and presents the content to be learned.

2. The lesson is planned with tasks (problem given by teacher) and problems (problematic from students), and promotes problem (problematic) awareness.

3. The teacher anticipated the methods and solutions.

1. The children can recall and apply what they have already learned.

2. The children's ideas are anticipated.

3. Inappropriate solutions are predicted, and advice and hints are prepared in advance.

4. The teacher, walks around, observes and helps children to ensure that children use mathematical representation to solve the problems.

5. Notes are written in a manner such that they will be helpful for presentation as well.

\section{Comparison and Discussion}

1. Steps (Validity, Compare, Similarity and Generalisation or Selection) are planned for comparative discussion.

2. The ideas to be taken up are presented in an order that is planned in advance.

3. The method for writing presentation sheets is planned in advance and directions are provided.

4. In addition to developing the ability to explain, children also foster the ability to listen and to question.

5. When ideas are brought together (generalised), it is important to experience them by

6. The reorganisation or integration of ideas proceeds smoothly from the presentation and the children's communication.

\section{Summary}

1. Activities are incorporated that let children experience for themselves the merits of the ideas and procedures that are generalised.

2. The summary matches the aims and problems (problematic) of this lesson.

3. It is recognised that both correct and incorrect answers (to the task) are good in the

4. Children are made to experience the joy and wonder of learning. 
2. Open classroom can be systematically organized and held within various environments. Number of observers and structure of the group of observers can vary. Lesson can be observed by just one person, usually master teacher. Group of observers can be consisted on school, regional or national basis and can include not only teachers but university lecturers and educational experts. If the group of observers is large, class can be placed in school gymnasium or lesson can be transmitted via school closed circuit television. Since classroom visits following the Lesson Study movement occurred in Japan on a regular basis from 1873, Japanese pupils have become accustomed to studying in such open setting (Sarkar Arani at all, 2010). Teachers who are observing the lesson examine the responses and behaviour of pupils to determine the degree of their interest in the lesson, and the suitability of the questions asked and of the resources used in teaching.

3. There are various themes of Lesson Study such as developing mathematical thinking, learning for/by themselves, development, reform or improvement of the curriculum. The chosen study topic depends on the various dimensions and focus of the open classroom and teachers' groups. The objective is specified at each class level in relation to the curriculum. The objective is often described by a sentence such as this: "Through A, students learn/ understand/are enabled to do B." Both learning how-to (A) and achievement (B) are objectives of curriculum. In the Lesson Study cycle, discussion and reflection are done after observation. It is necessary to talk about study topics and objectives, questioning the reason for each teacher's behavior in the teaching process.

4. The format of the lesson plan is not fixed but is usually developed or improved depending on the study topic. Lesson Study is implemented to generate new lesson plan formats and new teaching approaches avoiding uniformed forms of lesson plans. This means that the different lesson plan formats take into account the differences that arise from the local theories which are used to explain lesson planning and answer the questions about what, why and how we plan teaching and learning in a mathematics lesson.

5. Lesson study is conducted by teachers for developing pupils in a classroom and making each pupil developing him/herself. So, the focus is on pupils and not on researchers who just observe a classroom through their own lenses. In this sense, lesson study recommends that teachers are researchers who analyse pupils' understanding. At the same time, researchers are teachers who propose improvement (Isoda, 2011).

6. Usual consideration of Lesson Study is achievement in relation to study topic and objective. One of the most sharable products is description of model approaches. As results of Lesson Study we can find guidebooks for teaching contents and teaching approaches written by teachers. Also, videos have lately been used for sharing good approaches and practices by making them more visible. In the context of Lesson Study, a model approach means an illuminating approach and major resources for adapting a model into each teacher's classroom practice (Isoda, 2011).

7. The Lesson Study cycle continues beyond the present generation of teachers in the group. It is usually open to newcomers. Since Lesson Study is about teachers' daily activities, they repeatedly meet to discuss similar contents, themes and objectives of their lessons. However, during their teaching career the roles they take while participating in such projects differ. During one period a teacher may be a beginner but during an other, a facilitator in a group. Taking this into account, it is common over time to recognise similar experiences with the new challenges. That is the reason why Lesson Study brings the learning community beyond the present generation and why it is recognised as a reproductive practice in Japan, even if teachers are challenged with similar tasks and within different classroom settings. 
8. Even though Lesson Study is recognised as a teacher activity, it is, particularly in the case of the Japanese elementary school, seen as an activity of pupils. The open class which provides a scene for Lesson Study is not reserved for educators but is open also to parents. Pupils follow and try to follow their teacher's activity in order to show their progress to others, including perhaps their parents. In this particular aspect, we can recognise that Lesson Study has an additional function, and that is to develop pupils' ability to learn by/for themselves and in full view of their careers.

\section{The product of Lesson Study - Problem Solving Approach}

As Japanese teachers cannot recognise the theory of Mathematics education without considering their practice, Japanese Lesson Study functions as teachers' research activities. In Japan new theories of teaching approaches and curriculum development are recognised as products of Lesson Study. There are many guidebooks that offer theoretic advice to teachers to (re)produce good lessons. However, the movement to develop the theory of mathematics education which support the development of the curriculum and the teaching/learning practice is not limited to Japan. Even though outside of Japan Lesson Study is often perceived as professional development process, there is a tendency to recognise Lesson Study as research activity that could produce new theories in teaching approaches or theories of curriculum development.

One of teaching approaches and consecutive theories that arises from Japanese Lesson Study is Problem Solving Approach known as the process through posing a problem, independent solving, comparison and discussion, and summary and application. This approach became known in the world through the TIMSS Video Study in the 1990s (Stigler, Hiebert, 1999). Becker and Shimada (1997) explained the approach from the perspective of open-ended problems. Shimada's idea itself originated in the 1940s.
The basic principle of the Problem Solving Approach is to nurture children's learning of Mathematics by/for themselves, that is to develop children's ability to think and learn Mathematics by/for themselves. The Problem Solving Approach is the method of teaching used to teach content such as mathematical concepts and skills, and mathematical process skills such as thinking, ideas, and values (Isoda, Katagiri, 2011). The Problem Solving Approach distinguishes a problem - a task given by teacher, and a problem posed by pupils. This approach is not supposed to teach how to solve a problem (a task) but teaches how to approach a problem solving activity. The goal of lesson is achieved through problem solving. (Inprasitha, 2006). Glenn at al (2000: p.20) explained the Japanese teaching approach as follows: "In Japan, closely supervised, collaborative work among students is the norm. Teachers begin by presenting students with a mathematics problem employing principles they have not yet learned. They then work alone or in small groups to devise a solution. After a few minutes, students are called on to present their answers; the whole classworks through the problems and solutions, uncovering the related mathematical concepts and reasoning." Table 3 shows a model of Problem Solving Approach through teaching phases.

Teaching phases do not imply teaching step by step, neither are they obligatory. They could be modified based on circumstances related to topic, classroom, aims and goals of lesson etc. Even though there are variations, the phases are fixed for explaining the ways to develop mathematical thinking in class (Isoda, Katagiri, 2011). As it is noticeable from Table 3, Japanese teachers play several roles at each stage of their lessons. 
Table 3. Phases of the class for Problem Solving Approach

\begin{tabular}{lll}
\hline \multicolumn{1}{c}{ PHASE } & \multicolumn{1}{c}{ TEACHER'S ROLE } & \multicolumn{1}{c}{ PUPILS' STATUS } \\
\hline $\begin{array}{l}\text { Reviewing the previ- } \\
\text { ous lesson }\end{array}$ & $\begin{array}{l}\text { Asking questions related to } \\
\text { previous lessons }\end{array}$ & Bring in focus on mathematical ideas and learned facts. \\
\hline Posing the problem & $\begin{array}{l}\text { Posing the task with a hiden } \\
\text { objective }\end{array}$ & $\begin{array}{l}\text { Given the task in the context but not necessary to know the } \\
\text { objective of the class. }\end{array}$ \\
\hline $\begin{array}{l}\text { Planing and predict- } \\
\text { ing the solution }\end{array}$ & $\begin{array}{l}\text { Guiding the pupils to recog- } \\
\text { nise the objective; hatsumon. }\end{array}$ & $\begin{array}{l}\text { Having expectations, recognising known and unknown (prob- } \\
\text { lems) and approaches to problem solving. } \\
\text { Recognise and identify objectives of the lesson. }\end{array}$ \\
\hline $\begin{array}{l}\text { Independent (group) } \\
\text { solving/ executing } \\
\text { solutions }\end{array}$ & $\begin{array}{l}\text { Supporting individual work }- \\
\text { kikan-shido }\end{array}$ & $\begin{array}{l}\text { Bring in ideas to work on the task. In order to present some ex- } \\
\text { planations, clarify and bridge the known and unknown in each } \\
\text { approach. Try to present better ways. }\end{array}$ \\
\hline $\begin{array}{l}\text { Explanation and dis- } \\
\text { cussion, comparision } \\
\text { and validation }\end{array}$ & $\begin{array}{l}\text { Guiding discussion based on } \\
\text { the objective; hatsumon. }\end{array}$ & $\begin{array}{l}\text { Explaining each approach, compare approaches based on the } \\
\text { objective of the lesson. Communicate in order to understand } \\
\text { different ideas. Consider different ways in obtaining solutions } \\
\text { and conclusions. }\end{array}$ \\
\hline $\begin{array}{l}\text { Summarization; ap- } \\
\text { plication and further } \\
\text { development }\end{array}$ & $\begin{array}{l}\text { Guiding the reflection - } \\
\text { neriage }\end{array}$ & $\begin{array}{l}\text { Recognise and understand what students have learned. Ap- } \\
\text { preciate their own achievement, ideas and ways of thinking. } \\
\text { Re-evaluate contents through applying experience in new } \\
\text { circumstances. }\end{array}$ \\
\hline
\end{tabular}

Teachers' key roles are described by special pedagogical terms such as hatsumon, kikan-shido, neriage, bansho and matome. These can be described as follows.

a. Asking a key question in order to provoke students' thinking at a particular point in a lesson is known as hatsumon. At the beginning of the lesson, the teacher may ask a question for probing or promoting students' understanding of the problem. In a whole-class discussion, on the other hand, teacher may ask about the connections in between the proposed approaches to the problem or the efficiency and applicability of each approach.

b. Kikan-shido means an instruction at students' desk, the one-to-one discussion. Teacher is purposefully scanning students' problem solving on their own in the way that he/she is moving about the classroom, monitoring students' activities mostly si- lently and doing two important activities that are closely tied to the whole-class discussion that will follow. First, teacher assesses the progress of students' problem solving and if necessary suggests a direction for students to follow or gives hints to the students for approaching the problem. Second, he or she will make a mental note of several students who made the expected approaches or other important approaches to the problem. They will be asked to present their solutions later (Shimizu, 2006).

c. The term neriage acts as a metaphor for the process of "polishing" students' ideas and getting an integrated mathematical idea through a whole-class discussion. Based on his/her observations during kikan-shido, the teacher carefully- in particular order, calls on students, asking them to present their methods of solving the problem on the chalkboard. The order is quite impor- 
tant to the teacher both for encouraging those students who found naive methods and for showing students' ideas in relation to the mathematical connections that will be discussed later (Shimizu, 2006). An incorrect method or error may be presented in cases when teacher figures out that it would be beneficial for the class. Students' ideas are presented on the chalkboard, to be compared with each other with oral explanations. Teacher is supposed to guide the discussion by the students towards an integrated idea and to avoid pointing out the best solution. Japanese teachers regard neriage as critical for the success or failure of the entire lessons (Shimizu, 2006).

d. Effective use of blackboard is adressed as bansho. In Japan, the blackboard is used extensively in lessons: to keep a record of the lesson, to help students remember what they need to do and to think about, to help students see the connection between different parts of the lesson and the progression of the lesson, to compare, contrast, and discuss ideas that students present, to help to organize student thinking and discovery of new ideas (Takahashi, 2006) teachers use the blackboards. Teachers usually try to keep all that is written during the lesson on the blackboard without erasing it if possible, which gives both the students and teacher a birds-eye view of what has happened in the class at the end of each lesson. From the learner's perspective, it is easier to compare multiple solution methods if they appear on the blackboard simultaneously.

e. Matome means summing up, i.e. reviewing briefly what students have discussed in the whole-class discussion and summarising it by the teacher.

\section{Conclusion}

Significance of the Lesson Study goes far beyond professional development of teachers, as it is usually perceived outside Japan. Beside individual professional development, research lessons contribute to spread new content and approaches, connect individual teachers' practices to the school goals and broader goals, create demand for improvement, shape national policy and teach teachers to understand children better.

Recently, educators in many countries have begun to learn from their Japanese counterparts how to develop a new culture for promoting learning communities at their schools (Sarkar Arani et al., 2009). Collaborative lesson plans, participant observation, and reflective thinking on teaching are the three points that serve as the core of Lesson Study and should be highlighted in its application. It is essential that educators, as equal participants, clarify their own views toward education and pupils' learning. They have to present a collaborative lesson plans based on these aspects, and articulate their fundamental approaches to teaching. The final consideration is that Lesson Study should be understood as both regular practice and as a process, and that problems will not be resolved after a single session. Effective lesson study follows the teaching of pupils and their progress over a long period of time.

In the case of teaching and learning mathematics Lesson Study can shed a completely new light on how Mathematics is learnt by children and how the learning experience can be organized to help children not only to carry out techniques but make sense of the mathematics and focus on what is important to make mathematics both powerful and simple at the same time (Tall, 2008). Lack of understanding at one stage usually makes successive stages more difficult, leading to rote learning. Also, too much practice too soon can be ineffective or lead to math anxiety (Isaacs, Carroll, 1999). Lesson Study involves the careful design of good lesson sequences that focus on helping children develop different 
methods of approach from which they can find ways of working that are fast, easy and accurate. The lesson spends a significant amount of time reflecting on what makes sense and focusing on finding better ways of working. For the teacher, it requires not only knowledge of Mathematics, but also deep experience of how children think as they learn Mathematics (Tall, 2008). Lesson Study is not primarily focused on teaching techniques, but on upgrading conceptual understanding to level which lead to nourishing pupils who learn Mathematics by/for themselves. This requires an understanding not only of the Mathematics itself but how it can be organised to make sense in the long-term process of learning the subject.

Lesson Study in Mathematics goes beyond the design of individual lessons to the development of a long-term teaching approaches which are dedicated to understanding the nature of mathematical thinking. Lesson Study in Mathematics is fundamentally purposed to improve the nature of students' mathematical thinking, including not only the ability to perform routine tasks accurately and efficiently, but also to develop the abilities and attitudes to solve novel problems by thinking mathematically in new situations. As the result, new teaching theories have arisen, such as The Problem Solving Approach. In this way, Lesson Study is recognised as a reproductive science for teaching in the classrooms (Isoda, 2011). Therefore, there is a continued need for further implementation and future research on the lesson study model and its products. Recently, Lesson Study has become a widely-used and highly-refined methodology, not only in Japan, but also around the world. ${ }^{3}$ As it moves into different countries, local versions of lesson study may develop, using the overall structure to its best effect in different locations. In the case of Balkan countries, Lesson Study may be initiated on the basis of a well-established practice of exemplary lessons.

\section{References}

- Becker, J. P., Shimada, S. (1997). The Open-Ended Approach: A New Proposal for Teaching Mathematics. National Council of Teachers of Mathematics.

- Glenn, J. et al. (2000). Before It's Too Late. A report to the Nation from the National Commission on Mathematics and Science Teaching for the 21st Century. Retrieved June 23, 2014. from www.ed.gov/inits/Math/ glenn/report.pdf.

- Inprasihta, M. (2006). Open-Ended Approach and Teacher Education, Tsukuba Journal of Educational Study in Mathematics 25, 169-177.

- Isaacs, A. C., Carroll, W. M. (1999). Strategies for basic-facts instruction. Teaching Children Mathematics, 5(9), 508-515.

- Isoda, M. (2011). Problem Solving Approaches in Mathematics Education as a Product of Japanese Lesson Study, Journal of Science and Mathematics Education in Southeast Asia, 34(1), 2-25.

- Isoda, M., Katagiri, S.(2012). Mathematical Thinking: How to Develop it in the Classroom, Monographs on Lesson Study for Teaching Mathematics and Sciences, 1.

\footnotetext{
3 In US, the Lesson Study Research Group (LSRG) maintains a central database of U.S. lesson study groups, initiatives, and related activity. http://www.tc.columbia.edu/lessonstudy/. In UK, see http://lessonstudy.co.uk/the-lesson-study-process/. In Malaysia, the first Lesson Study project was initiated in 2004 (Lim, White, Chiew, 2005)
} 
- Isoda, M., Olfos, R., (2009). El Enfoque de Resolución de Problemas: En la Enseñanza de la Matemática. Valparaíso: Ediciones Universitarias.

- Lewis, C. (2006). Lesson Study in North America: Progress and Challenges. In: Matoba, M., Crawford, K. A., Sarkar Arani, M. R. (ed.) Lesson study: International Perspective on Policy and Practice. Educational Science Publishing House, Beijing. Retrieved November, 4, 2014. from http://www.lessonresearch.net/internationalls.pdf.

- Lim, C. S, White, A., Chiew, C. M. (2005). Promoting Mathematics Teacher Collaboration through Lesson Study: What Can We Learn from Two Countries Experience. In Rogerson, A. (Ed.), Proceedings of the 8th International Conference of The Mathematics Education into the 21 st Century Project:"Reform, Revolution and Paradigm Shifts in Mathematics Education", 135-139.

- Makinae, N. (2010). Characteristics of Japanese mathematics lessons. In: Proceedings of the 5th East Asia Regional Conference on Mathematics Education EARCOME 5, Retrieved December 21, 2013 from http://www. lessonstudygroup.net/lg/readings/TheOriginofLessonStudyinJapanMakinaeN/TheOriginofLessonStudyinJapanMakinaeN.pdf.

- Matoba, M., Shibata, Y., Sarkar Arani, M. R. (2007). School-University Partnerships: A New Recipe for Creating Professional Knowledge in School, International Journal of Educational Research for Policy and Practice, 6.

- Sarkar Arani, M. R., Fukaya, K., Lassegard, J. P. (2010). Lesson Study as Professional Culture in Japanese Schools: An Historical Perspective on Elementary Classroom Practices, Japan Review 22, 171-200.

- Stigler, J., Hiebert, J. (1999). The Teaching Gap. Free Press, New York.

- Shimizu, Y. (2007). How do Japanese Teachers Explain and Structuralize Their Lessons?, In Isoda, M., Stephens, M., Ohara, Y. Miyakawa, T. (ed.): Japanese Lesson Study in Mathematics - Its Impact, Diversity and Potential for Educational Improvement (64-67). World Scientific Publishing.

- Tall, D. (2008). Using Japanese Lesson Study in teaching mathematics, The Scottish Mathematical Council Journal, 38, 45-50.

- Takahashi, A. (2006). Characteristics of Japanese mathematics lessons. Tsukuba Journal of Educational Study in Mathematics 25. Retrieved April 24, 2012. from http://www.criced. tsukuba.ac.jp/math/sympo_2006/ takahashi.pdf.

- Takahashi, A., Yoshida, M. (2004). Ideas for Establishing Lesson-Study Communities, Teaching Children Mathematics, 10(9), 436-443. 


\section{др Кармелита Пјанић}

Педагошки факултет, Универзитет у Бихаћу, Босна и Херцеговина

\section{Порекло и производ јапанске „студије часа“}

Циљ овог рада је да се прикаже „студија часа“ и њен главни производ - „приступ решавања проблема“, заснован на релевантном проучавању литературе и директној опсервацији аутора рада. Јапанска „студија часа“ се препознаје као успешна методологија у математичком образовању. У западним земљама „студија часа“ се обично схватала као професионални развојни процес који је укључивао јапанске наставнике да систематично испитују своју праксу ради њене веће ефикасности. Међутим, „студија часа“ је више од професионалног развоја. Реч је о наставној активности заснованој у науци и у методологији осамдесетих година 19. века (Isoda, 2011). Порекло „студије часа“ може да буде забележено у образовној пракси у периоду Меији у Јапану, где су људи посматрали начине поучавања да би знали како да воде процес поучавања и учења. Од тада „студија часа“ функционише као средство које омогућава наставницима да развијају и проучавају властиту наставну праксу и да учине познатијим локалне теорије образовања. Овај развој се одвија због димензија које карактеришу 'студију часа' као процес колаборативних активности и истраживања које није примарно фокусирано на технологију и средства, већ на садржај и ученике. Производи „студије часа“ нису само ограничени на оно што су учесници научили из одређене рефлексивне дискусије у оквиру часа и после њега. То такође укључује развој локалних теорија у математичком образовању. „Студија часа“ функционише као репродуктивна наука која нам приближава локалне теорије у математичком образовању, које су препознате са наставном праксом која произлази из њих. Једна од теорија поучавања математике, која се појавила из „студије часа“, јесте „приступ решавања проблема“, познат као јапански начин поучавања и теорија поучавања и учења (Stigler \& Hiebert, 1999). 'Приступ решавања проблема' је приступ поучавања који се користи да би се формирали математички појмови и развиле математичке вештине - математичко мишљење, идеје и вредности (Isoda \& Katagiri, 2011). Основни принцип „приступа решавања проблема“ је да се деца науче да уче математику сама, тј. да се настоји у томе да се развијају деца која размишљају и која уче математику за себе. Однедавно је „студија часа“ постала широко примењена не само у Јапану већ и широм света. Пошто је све више присутна у разним земљама, локалне верзије „студије часа“ могу да се развијају коришћењем комплетне структуре на најбољи начин на разним локацијама. У случају балканских земаља, „студија часа“ може да буде базирана на добро заснованој пракси огледних часова.

Клучне речи: „студија часа“, „приступ решавања проблема“, математичко образовање. 